\title{
Dossier "Anthropology and Kinship"
}

Foreword

\section{Márcio Silva \& Adriana Piscitelli}

It would be somewhat redundant to state again that the study of kinship lies at the heart of anthropology. Yet there is a hiatus between the studies of societies we might call complex and those we may term exotic. The advantages of an interchange between studies of kinship in complex and exotic societies are clear to us and lie behind the motives for organizing this dossier. What we had in mind was, in the spirit of interdisciplinary within anthropology to bring together researchers of kinship who generally don't meet one another in scientific events. While the articles are quite distinct in terms of the problems raised and the subjects and research methods they are presented here together in the hope that proximity between them will lead to understandings, which would not emerge were they to be looked at separately. This dossier is therefore an attempt to give rein to new encounters. The labels of complex and exotic were not chosen at random: such adjectives are not antonyms and nor are the problems raised in articles that have been forged in the two traditions.

The dossier is composed of fourteen articles based on ethnographic research, of which ten look at kinship in complex societies and four in exotic societies. Written originally in 1970, Antonio Augusto Arantes Neto's article presents a structural analysis of ritual kinship (compadrio) among peasant communities in the backlands of Bahia. Written under the supervision of Edmund Leach but never before published, it includes as postscript correspondence between the author and his supervisor. Débora Allebrandt compares discussions on international adoption and assisted reproduction to reflect upon kinship theories that contribute to the understanding of tensions present in notions of the family and conceptions of what is considered natural. Flávio Tarnovski, who conducted research among homosexual parents in France looks at the specificities of co-parenthood among gays and lesbians. Juliane Bazzo examines the tensions between kinship, rights over territory, and state controls over the environment in a small fishing community in the state of Paraná in an area that is suffering from intense natural erosion. Andréa Lobo's paper is based on research in Cabo Verde. Paying particular 
attention to children, who are perceived as central actors in the inter-subjective relations that constitute kinship in that society, she argues that kinship which is characterized by mutual commitments, regular social contacts and a flux of material and non-material exchanges both within and between domestic groups is not predefined by consanguinity but rather through constant negotiation.

In his paper, Igor José de Renó Machado analyzes the relations between kinship and migration through a study of two distinct ethnographic situations: the international migration from the region of Governador Valadares in the state of Minas Gerais, and Japanese immigration to Brazil. Juliana P. Lima Caruso's article examines the connections between "flight" (fuga) which is a form of consensual marriage common in a community in the city of Florianopolis, and kinship, arguing that this type of marriage is a way of circumventing possible marriage prohibitions. Pedro Nascimento's article which is based on research in a public hospital providing assisted reproduction, and in suburban communities of Porto Alegre, discusses how different ways of establishing kinship, especially adoption, emerge in the context of reproductive technologies. Kinship links have a hybrid quality and the sharing of "biogenetic substance" is not the only aspect to create "diffuse and lasting solidarity". Parry Scott discusses issues of kinship, gender and generation, by employing the genealogical method as a tool for understanding the logic of relatedness and mobility in an analysis of international female migration from Recife. Claudia Fonseca raises the problem of adoption by taking into account the experiences of birth mothers and showing how the process of legal adoption in Brazil constitutes a form of violence organized by the State against these women.

Odair Giraldin's article is a study of formal friendship and marriage alliances among the Apinajé, who belong to the northern Jê. For her part, Cinthia Creatini da Rocha writes on a southern Jê people, the Kaingang. Attention is focused on the dynamics established between kinship networks and sociopolitical processes of schism and alliance between groups. Jovane Gonçalves dos Santos establishes a dialogue between material gathered during an ethnography of a Nhandéva community in the state of Paraná and the literature on Guarani kinship. Finally, Gabriel O. Alvarez returns to the classic debate on Tupi kinship in the light of his research among the Sateré-Mawé, with particular emphasis on the articulation between kinship and the ritual sphere. 